\title{
Editor's Column Who Writes for PMLA?
}

MOST of the criticisms of the MLA I hear compare the present unfavorably to the past, and one of the more common is that PMLA no longer publishes much work by distinguished senior scholars. The authors in the recently completed 1983 volume, whatever their rank, need no apology; they wrote distinguished essays that will bear comparison to any of the ninety-seven preceding volumes of $P M L A$. My scholarly habits, however, prompted me to visit the archives to see what the truth was. I compared sample volumes at ten-year intervals and made a table of authors published, by rank; the annual presidential address is omitted:

\begin{tabular}{lcccccc} 
& \multicolumn{2}{c}{1963} & \multicolumn{2}{c}{1973} & \multicolumn{2}{c}{1983} \\
& Number & Percentage & Number & Percentage & Number & Percentage \\
\cline { 2 - 7 } Professor & 12 & 17 & 13 & 26 & 6 & 26 \\
Associate Professor & 15 & 21 & 13 & 26 & 4 & 17 \\
Assistant Professor & 24 & 33 & 19 & 37 & 10 & 43 \\
Other & $\mathbf{2 1}$ & 29 & $\mathbf{6}$ & 12 & $\mathbf{3}$ & 13 \\
TOTAL & 72 & & 51 & & 23 &
\end{tabular}

These samples are too small to support large conclusions, and the distributions shifted significantly from year to year; in 1965 there were more full and associate professors, fewer assistant professors and others. Nonetheless, the figures suggest to me that $P M L A$ authors have come from all ranks in substantial numbers for the past two decades, despite the vast changes in the profession and some important revisions in $P M L A$ 's policies and procedures. We have much more complete computerized statistics from 1973 onward; they are summarized in the tables below, but since they are based on year of submission, you will not be able to match them to the published issues. The first table shows percentage of submissions by rank. For ten years, the distribution has held fairly steady. Submissions by full professors actually show a slight rise, probably reflecting a generally older faculty. Associate professors have stayed within one percent of the ten-year average. The number of assistant professors has declined steadily, but part of the decline has been absorbed by the "other" category, predominantly junior rather than senior positions.

\begin{tabular}{lccccc} 
Year & $\begin{array}{c}\text { Total } \\
\text { Submitted }\end{array}$ & $\begin{array}{c}\text { Percentage of } \\
\text { Professors }\end{array}$ & $\begin{array}{c}\text { Percentage of } \\
\text { Associate } \\
\text { Professors }\end{array}$ & $\begin{array}{c}\text { Percentage of } \\
\text { Assistant } \\
\text { Professors }\end{array}$ & $\begin{array}{c}\text { Percentage of } \\
\text { Others }\end{array}$ \\
\hline 1973 & 355 & 15 & 20 & 42 & 24 \\
1974 & 468 & 15 & 21 & 39 & 24 \\
1975 & 515 & 15 & 19 & 41 & 25 \\
1976 & 656 & 18 & 19 & 38 & 25 \\
1977 & 659 & 17 & 20 & 34 & 30 \\
1978 & 607 & 19 & 19 & 32 & 29 \\
1979 & 610 & 19 & 19 & 33 & 30 \\
1980 & 424 & 17 & 20 & 32 & 25 \\
1981 & 432 & 21 & 21 & 28 & 30 \\
1982 & 476 & 18 & 20 & 35 & 27 \\
TOTAL & 5,373 & & & &
\end{tabular}

The total includes partial figures for 1983 . 
A table of acceptances does not disclose any sharp differences. The first two years seem to have been better than normal for full professors, but that is probably no more than a quirk.

\begin{tabular}{cccccc} 
Year & $\begin{array}{c}\text { Total } \\
\text { Accepted }\end{array}$ & Professor & $\begin{array}{c}\text { Associate } \\
\text { Professor }\end{array}$ & $\begin{array}{c}\text { Assistant } \\
\text { Professor }\end{array}$ & Other \\
\hline 1973 & 29 & 11 & 7 & 8 & 3 \\
1974 & 26 & 9 & 6 & 8 & 3 \\
1975 & 30 & 8 & 7 & 10 & 5 \\
1976 & 40 & 10 & 9 & 16 & 5 \\
1977 & 39 & 7 & 9 & 12 & 11 \\
1978 & 20 & 6 & 7 & 7 & 3 \\
1979 & 31 & 4 & 7 & 15 & 3 \\
1980 & 20 & 5 & 3 & 10 & 3 \\
1981 & 18 & 6 & 3 & 7 & 10 \\
1982 & 25 & $70(25 \%)$ & $67(25 \%)$ & $103(37 \%)$ & $40(14 \%)$ \\
TOTAL & 280 & & & &
\end{tabular}

The total includes partial figures for 1983 .

I would propose two commonsense explanations for the pervasive myth of a golden age of PMLA: first, our almost universal penchant for nostalgia and, second, the fact that many of the lowerranking authors were soon promoted and became well known. Common sense might also lead one to expect a higher percentage of full professors among the authors, but a little probing brought me to the following conclusions: full professors have promised most of their work to particular editors before they even begin writing (in my case, alas, often before I began thinking of a subject) and rarely have a major piece of work available to send out unsolicited; by contrast, ambitious assistant professors are looking for the journal with the greatest exposure and the most rigorous editorial standards, namely, $P M L A$.

Of the 73 authors published in 1963, 10-or about 14\%-were women, if first names are a reliable gender sign. Using submissions records since 1973, I find that 80 of 280 accepted authors were women, about $29 \%$. That percentage is still somewhat below the submission rate, which has been quite steadily near $35 \%$ women, but it includes the four years from 1973 to 1976 when the acceptance rate for men was almost twice as high as for women. Since 1977 it has been virtually identical: $4.8 \%$ for men, $4.4 \%$ for women. The submissions rate itself is somewhat below the estimated percentage of female MLA members and probably means that women are still less likely than men to be located at research institutions.

Statistics on institutional affiliation show a very broad spread. The 280 acceptances come from 146 different campuses; only 54 are represented more than once and only 7 more than five times. The leaders are:

$\begin{array}{lr}\text { Yale } & 14 \\ \text { Princeton } & 9 \\ \text { University of California, Berkeley } & 8 \\ \text { City University of New York (all campuses) } & 8 \\ \text { University of Virginia } & 7 \\ \text { University of Illinois, Urbana } & 6 \\ \text { University of Minnesota } & 6\end{array}$

Tied at 5 are State University of New York, Buffalo; University of California, Davis; University of California, Santa Barbara; Columbia; Rochester; and Rutgers, New Brunswick; tied at 4, Boston University, Cornell, Pittsburgh, and Texas, Austin.

These figures go back to the period before $P M L A$ adopted the policy of anonymous submissions; it will be interesting to see what trends emerge as a result of the change. Certainly women have already benefited, and a male author told me he thought his article would have been turned down if his institutional affiliation had been known to the readers.

The justification for anonymous submission, however, is the principle that who is in PMLA matters less than what is in $P M L A$. A glance at the first table above will show that the most striking change over two decades has been the decline in the number of articles published. Inevitably, this 
trend has reduced $P M L A$ 's coverage of our diverse fields of interest, especially in foreign languages. In the October issue of PMLA I plan to analyze the articles by subject matter and discuss the evolution of the journal toward fewer but longer articles.

For those of you interested in earlier statistics, the four Newsletters between October 1977 and Summer 1978 carried a profile of PMLA. In the 1973 Directory William Pell published the fifth in an irregular series called "Facts of Scholarly Publishing." $P M L A$ is included, but the analysis is not based on the kind of information we have kept since 1973. In fact, the MLA Directory of Periodicals (which now appears biennially) contains the same information, but for more than ten times the number of journals. In December 1958, to celebrate the MLA's seventy-fifth anniversary, $P M L A$ issued a special supplementary volume that included an article by Richard F. Bauerle, "A Statistical Survey of PMLA, Its Contributors, and Their Institutions" (72-78). There were sixtynine individual scholars who had published six or more articles in PMLA by then, and in 1957 the acceptance rate was twenty-four percent of manuscripts submitted. Maybe it was a golden age.

ENGLish Showalter

\section{Notes on Contributors}

Paul B. Armstrong taught at the University of Virginia from 1976 to 1983 , when he became associate professor of English at the Georgia Institute of Technology. In addition to a book, The Phenomenology of Henry James (Univ. of North Carolina Press, 1983), he has published essays on James, Conrad, Ford, Forster, Kierkegaard, and critical theory. His PMLA article "The Conflict of Interpretations and the Limits of Pluralism"' (May 1983) won the association's William Riley Parker Prize. He is currently working on books on literary impressionism and on the theory of interpretation.

LAwRENCE Danson did graduate work at Oxford and received his Ph.D. from Yale in 1969. He is professor of English at Princeton, where he has taught since 1968, and regularly teaches at the Bread Loaf School of English in Middlebury. He has published extensively on Renaissance drama, including his books Tragic Alphabet: Shakespeare's Drama of Language (Yale Univ. Press, 1974), The Harmonies of The Merchant of Venice (Yale Univ. Press, 1978), and an edited volume of essays, On King Lear (Princeton Univ. Press, 1981). He has written articles on Shakespeare, Marlowe, and Max Beerbohm.

ADELE DAvidson did her undergraduate work at Kenyon College and received the M.A. from the University of Virginia, where she is writing a dissertation on the topic "Dying into Life: A Study of Shakespeare's Pericles." A graduate instructor at the University of Virginia, she has also taught at Bowdoin College.

EDwin M. Duval received his Ph.D. from Yale in 1973 and has taught at Princeton and the University of California at Santa Barbara, where he is now associate professor of French. His publications include a book, Poesis and Poetic Tradition in the Early Works of Saint-Amant (French Literature Publications, 1981), and articles on Rabelais, Montaigne, Scève, and Ronsard. He held an ACLS fellowship in 1976-77 and currently holds a Guggenheim fellowship to work on a study tentatively called "The Design of Rabelais's Christian Humanist Epics."

SANDRA M. GnBERT, professor of English at the University of California at Davis, took her Ph.D. at Columbia in 1968. She is well known to MLA members as a member of the Executive Council since 1981. Besides several collections of her own poetry, she has published a book on D. H. Lawrence, coedited an anthology of feminist essays on women poets, written many articles and given many papers-especially on women writers and feminist literary theory-and coauthored (with Susan Gubar) the celebrated study The Madwoman in the Attic (Yale Univ. Press, 1979). At present, she and Susan Gubar are preparing a Norton Anthology of Literature by Women, as well as a sequel to The Madwoman.

A. Kent Hifatt taught at Columbia University before becoming professor of English at the University of Western Ontario in 1969. He has written extensively on topics in Old, Middle, and Renaissance English literature.

DAVID KRAUSE is an assistant professor at Marquette University. He received his Ph.D. from Yale in 1979 and has taught Shakespeare, American literature, and literary criticism at Marquette since 